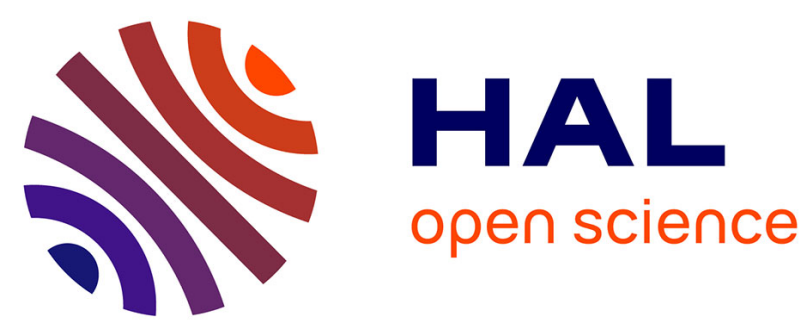

\title{
European and International validation of 15 main reference methods in the microbiology of the food chain
}

Alexandre Leclercq, Gwenola Hardouin, Bertrand Lombard

\section{To cite this version:}

Alexandre Leclercq, Gwenola Hardouin, Bertrand Lombard. European and International validation of 15 main reference methods in the microbiology of the food chain. International Journal of Food Microbiology, 2019, 288, pp.1-2. 10.1016/j.ijfoodmicro.2018.10.024 • pasteur-02586139

\section{HAL Id: pasteur-02586139}

https://hal-pasteur.archives-ouvertes.fr/pasteur-02586139

Submitted on 27 May 2020

HAL is a multi-disciplinary open access archive for the deposit and dissemination of scientific research documents, whether they are published or not. The documents may come from teaching and research institutions in France or abroad, or from public or private research centers.
L'archive ouverte pluridisciplinaire HAL, est destinée au dépôt et à la diffusion de documents scientifiques de niveau recherche, publiés ou non, émanant des établissements d'enseignement et de recherche français ou étrangers, des laboratoires publics ou privés.

\section{(1)(1) $\$(0)$}

Distributed under a Creative Commons Attribution - NonCommercial - ShareAlikel 4.0 


\title{
European and International validation of 15 main reference methods
}

\section{in the microbiology of the food chain}

\begin{abstract}
A large amount of qualitative and quantitative analytical results are produced internationally on a daily basis by laboratories involved in the microbiological testing of the food chain. These results are used by food business operators and risk managers to ensure food safety for consumers and fair trade of goods. To avoid the use of multiple methods for the same target, standardization bodies are developing and validating harmonised reference methods. Moreover, with quality management and accreditation of testing laboratories, it is widely accepted that only validated methods should be used to meet the customers' need of reliable results.
\end{abstract}

At international level, it is the task of the Sub-Committee 9 Microbiology of Technical Committee 34 Food products of ISO, the International Organization for Standardization (ISO/TC 34/SC 9). At regional level in Europe, Working Group 6 Microbiology of the food chain of the Technical Committee 275 Food analyses - Horizontal methods of CEN, the European Committee for Standardisation (CEN/TC 275/WG 6) is entrusted to this task (Leclercq et al., 2015). These two structures develop, validate and standardize common reference methods under the CEN/ISO collaboration Vienna agreement. Until 1996, standardized reference methods were mainly based on recognized experts' opinion or "historically proven" methodologies without performance characteristics derived from proper interlaboratory studies. The current policy of ISO/TC 34/SC 9 and CEN/TC 275/WG 6 requires a full validation of reference methods based on collaborative studies for inclusion of resulting performance characteristics in CEN/ISO standards (Anonymous, 2016c). 
In order to include performance characteristics in CEN/ISO standardized reference methods, a first European project, Project SMT4-CT96-2098 financed by European Commission under the fourth Framework Standards, Measurements and Testing Program (SMT4) was conducted between 1997 and 2000 to determine the performance characteristics (repeatability and reproducibility of quantitative methods or sensitivity, specificity, accordance and concordance of qualitative methods) of six CEN/ISO reference methods (De Buyser et al., 2003; Lahellec, 1998; Lombard et al., 2005; Schulten et al., 2000; Scotter, Langton, Lombard, Lahellec, et al., 2001; Scotter, Langton, Lombard, Schulten, et al., 2001). These standardized methods concerned Bacillus cereus enumeration (EN ISO 7932:2004), Listeria monocytogenes detection and enumeration (EN ISO 11290-1:1996 and EN ISO 11290-2:1998), coagulase positive staphylococci enumeration (EN ISO 6888-1:1999 and EN ISO 68882:1999), Clostridium perfringens enumeration (EN ISO 7937:2004) and Salmonella detection (EN ISO 6579:2002) (Anonymous, 1996, 1998, 1999a, b, 2002, 2004a, b). The determined performance characteristics have been included in the respective CEN/ISO Standards. They have allowed to (i) risk managers to know the performance of the methods that are used in official controls to verify conformity of foodstuffs to legal microbiological criteria, (ii) food operators to rely on methods used by food testing laboratories and fit for their purpose, (iii) food testing laboratories to verify their compliance to the method's performance characteristics in the frame of their EN ISO 17025 accreditation (Anonymous, 2005b), and (iv) validation/certification bodies to validate alternative proprietary methods against these reference methods, according to EN ISO 16140 and since 2016, EN ISO 16140-2 (Anonymous, 2003, 2016b).

Further to the validation of these first 6 standardized reference methods and for similar purposes, European Commission signed a specific grant agreement in December 2010 with CEN (known as CEN Mandate $\mathrm{M} / 381$ ) to finance the validation and standardization (or revision) of 15 methods for the main micro-organisms or their toxins in the field of food chain microbiology. These validations were in particular necessary to correctly set and implement microbiological criteria at European level, either already included in Commission Regulation (EC) No 2073/2005 (Anonymous, 2005a), or to be 
possibly included at a later stage in future amendments to this regulation (i.e. Norovirus, Hepatitis A, Bacillus cereus toxins). The 15 validation trials were carried out between 2012 and 2017 by a total of 150 laboratories in 35 countries with a budget of 3120000 euros, representing the largest worldwide validation effort of standardized methods in microbiology of the food chain.

In this special issue, the detailed validation studies of each reference method are described in separate articles, except for the reference method for detection of staphylococcal enterotoxins. An harmonized experimental design for the organization of collaborative studies has been followed (Anonymous, 2005c, 2010, 2014). The 15 reference methods which were validated are mostly microbiological methods, except two chemical methods, for quantification of histamine and Bacillus cereus toxins (cereulide) and one biochemical method, for detection of staphylococcal enterotoxins. Thus, two statistical approaches were used for the determination of performance characteristics: an approach designed for microbiological analysis and derived from EN ISO 16140-2 (Anonymous, 2016a, b) and an approach more suited for chemical methods, derived from ISO 5725-2 (Anonymous, 1994).

Alexandre Leclercq*, Convenor of CEN TC275/WG6, Institut Pasteur, Biology of Infection Unit, National Reference Centre and WHO Collaborating Centre for Listeria, Paris, France.

Gwenola Hardouin, Secretary of CEN/TC 275/WG 6 \& ISO/TC 34/SC 9, AFNOR, Saint-Denis, France.

Bertrand Lombard, Chairman of ISO/TC 34/SC 9 (formerly), French Agency for Food, Environmental, Occupational Health \& Safety (ANSES), Laboratory for Food Safety, Maisons-Alfort, France

${ }^{*}$ Corresponding associate editor. Tel. +33(0)140613190. Fax: +33(0)140613567. Email: alexlec@pasteur.fr 


\section{Acknowledgments}

The European and international validation of 15 main reference methods in the microbiology of the food chain was carried out under the framework of European Mandate No. M381 of DG SANTE and DG GROW (European Commission) and was allowed by the participation and coordination of 150 laboratories in the method characterisation and /or interlaboratory study.

\section{Reference}

Anonymous, 1994. EN ISO 5725-2: Accuracy (trueness and precision) of measurement methods and results -- Part 2: Basic method for the determination of repeatability and reproducibility of a standard measurement method. International Organization for Standardization, Geneva.

Anonymous, 1996. EN ISO 11290-1:1996. Microbiology of food and animal feeding stuffs -- Horizontal method for the detection and enumeration of Listeria monocytogenes -- Part 1: Detection method. Internation Organization for Standardization, Geneva, Switzerland.

Anonymous, 1998. EN ISO 11290-2:1998. Microbiology of food and animal feeding stuffs -- Horizontal method for the detection and enumeration of Listeria monocytogenes -- Part 2: Enumeration method. International Organization for Standardization, Geneva, Switzerland.

Anonymous, 1999a. EN ISO 6888-1:1999. Microbiology of food and animal feeding stuffs -- Horizontal method for the enumeration of coagulase-positive staphylococci (Staphylococcus aureus and other species) -- Part 1: Technique using Baird-Parker agar medium. International Organization for Standardization, Geneva, Switzerland.

Anonymous, 1999b. EN ISO 6888-2:1999. Microbiology of food and animal feeding stuffs -- Horizontal method for the enumeration of coagulase-positive staphylococci (Staphylococcus aureus and other species) -- Part 2: Technique using rabbit plasma fibrinogen agar medium. Internation organization for Standardization, Geneva, Switzerland.

Anonymous, 2002. EN ISO 6579:2002. Microbiology of food and animal feeding stuffs -- Horizontal method for the detection of Salmonella spp. International Organization for Standradization, Geneva, Switzerland.

Anonymous, 2003. EN ISO 16140:2003. Microbiology of food and animal feeding stuffs - Protocol for the validation of alternative methods. International Organization for Standardization, Geneva, Switzerland.

Anonymous, 2004a. EN ISO 7932:2004. Microbiology of food and animal feeding stuffs -- Horizontal method for the enumeration of presumptive Bacillus cereus -- Colony-count technique at 30 degrees C. International Organization for Standardization, Geneva, Switzerland.

Anonymous, 2004b. EN ISO 7937:2004.Microbiology of food and animal feeding stuffs -- Horizontal method for the enumeration of Clostridium perfringens -- Colony-count technique. International Organization for Standardization, Geneva, Switzerland. 
Anonymous, 2005a. Commission Regulation (EC) No 2073/2005 of 15 November 2005 on microbiological criteria for foodstuffs. Official Journal of the European Union of 22/12/2005. L338 (2005), pp. 1-26.

Anonymous, 2005b. EN ISO 17025: 2005.General requirements for the competence of testing and calibration laboratories. International Organization for Standardization.

Anonymous, 2005c. ISO 13528: 2005. Statistical methods for use in proficiency testing by interlaboratory comparison. International Sandardization Organization, Geneva, Switzerland.

Anonymous, 2010. EN ISO 17043: 201. Conformity assessment -- General requirements for proficiency testing. International Organization for Standardization, Geneva, Switzerland.

Anonymous, 2014. CEN/TC 275/ WG6/Mandate M/381 Document Number N 20. Evaluation and presentation of validation data. AFNOR, Saint-Denis, France.

Anonymous, 2016a. EN ISO 16140-1: 2016. Microbiology of the food chain -- Method validation -Part 1: Vocabulary. International Organization for standardization, Geneva, Switzerland.

Anonymous, 2016b. EN ISO 16140-2: 2016. Microbiology of the food chain -- Method validation -Part 2: Protocol for the validation of alternative (proprietary) methods against a reference method. International Organization for standardization, Geneva, Switzerland.

Anonymous, 2016c. EN ISO 17468: Microbiology of the food chain - Technical requirements and guidance on establishment or revision of a standardized reference method. International Organization for standardization, Geneva, Switzerland.

De Buyser, M.L., Lombard, B., Schulten, S.M., In't Veld, P.H., Scotter, S.L., Rollier, P., Lahellec, C., 2003. Validation of EN ISO standard methods 6888 Part 1 and Part 2: 1999--enumeration of coagulase-positive staphylococci in foods. Int J Food Microbiol 83, 185-194.

Lahellec, C., 1998. Development of standard methods with special reference to Europe. Int J Food Microbiol 45, 13-16.

Leclercq, A., Hardouin, H., Lombard, B., 2015. Chapter 5 - CEN/ISO standards for both culture and molecular methods, in: Cook, N., D'Agostino, M., Thompson, K.C. (Eds.), Molecular Microbial Diagnostic Methods: Pathways to Implementation for the Food and Water Industries. Elsevier, Academic Press, London, United Lingdom, pp. 79-106.

Lombard, B., Cornu, M., Lahellec, C., Feinberg, M.H., 2005. Experimental evaluation of different precision criteria applicable to microbiological counting methods. J AOAC Int 88, 830-841.

Schulten, S.M., In't Veld, P.H., Nagelkerke, N., Scotter, S.L., De Buyser, M.L., Rollier, P., Lahellec, C., 2000. Evaluation of ISO 7932 standard for the enumeration of Bacillus cereus in foods. Int. J. Food Microbiol. 57.

Scotter, S.L., Langton, S., Lombard, B., Lahellec, C., Schulten, S., Nagelkerke, N., in't Veld, P.H., Rollier, P., 2001. Validation of ISO method 11290 part 2. Enumeration of Listeria monocytogenes in foods. Int J Food Microbiol 70, 121-129.

Scotter, S.L., Langton, S., Lombard, B., Schulten, S., Nagelkerke, N., In't Veld, P.H., Rollier, P., Lahellec, C., 2001. Validation of ISO method 11290 part 1--Detection of Listeria monocytogenes in foods. Int J Food Microbiol 64, 295-306. 